\title{
Breed and seasonal variation in thermoregulatory paramters of some selected Nigerian indigenous cattle
}

${ }^{1}$ Abbaya, H. Y., ${ }^{2}$ Adedibu, I. I., ${ }^{2}$ Kabir, M. and ${ }^{3}$ Iyiola-Tunji, A. O

${ }^{\prime}$ Department of Animal production, Adamawa state University,

PMB 025 Mubi, Adamawa State.

${ }^{2}$ Department of Animal Science, Ahmadu Bello University, Zaria, PMB 1044, Zaria.

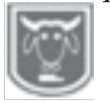

Abstract

${ }^{3}$ National Agricultural Extension and Research Liaison Services,

Ahmadu Bello University, Zaria,

Corresponding author: abbaya177@gmail.com

The study was conducted to evaluate breed differences in thermoregulatory parameters of four Nigerian indigenous breeds of cattle over two seasons (late rainy and late dry). Data on thermoregulatory parameters (rectal temperature, respiratory rate, pulse rate and Heat Tolerance Coefficient) of eighty (80) cattle, comprising 20 each of Bunaji, Rahaji, Bokoloji and Adamawa Gudali were obtained and subjected to analysis of variance of SAS software. In the pooled breed variation, breed influenced $(p<0.05)$ all the parameters measured. Bunaji recorded the highest rectal temperature $\left(37.92^{\circ} \mathrm{C}\right)$ in all the seasons of measurement. Respiratory rate and Heat tolerance coefficient were highest in Bokoloji while the least were in Bunaji and Adamawa Gudali. Season significantly $(p<0.05)$ affected thermoregulatory parameters measured except $(p>0.05)$ rectal temperature. The highest recorded values of respiratory rate (27.85 beat/min), Pulse rate (27.62 breaths/min) and HTC (2.19) were in the late dry season. The effect of interaction between breed and season on thermoregulatory parameters significantly affected $(p<0.05)$ all the thermoregulatory parameters measured. It was concluded that Bokoloji and Bunaji breeds of indigenous cattle are more reactive to Heat stress than Rahaji and Adamawa Gudali even though this could vary with seasons of the year as seen in the interaction between breed and season in this study.

Keywords: breed, thermoregulation, indigenous, cattle

\section{Des Races et variations saisonnières des paramètres thermorégulateurs de certains} bovins indigènes nigérians sélectionnés

\section{Résumé}

L'étude a été menée pour évaluer les différences entre les races dans les paramètres thermorégulateurs de quatre races indigènes de bétail nigérianes sur deux saisons (pluvieuse tardive et sèche tardive). Des données sur les paramètres thermorégulateurs (température rectale, fréquence respiratoire, fréquence du pouls et coefficient de tolérance à la chaleur) de quatre-vingts (80) bovins, comprenant 20 de chacun de Bunaji, Rahaji, Bokoloji et Adamawa Gudali ont été obtenues et soumises à l'analyse de variance du logiciel 'SAS'. Dans la variation de race combinée, la race a influencé $(p<0,05)$ tous les paramètres mesurés. Bunaji a enregistré la température rectale la plus élevée $\left(37,920^{\circ} \mathrm{C}\right)$ de toutes les saisons de mesure. La fréquence respiratoire et le coefficient de tolérance à la chaleur étaient les plus élevés à Bokoloji tandis que les plus faibles étaient à Bunaji et à Adamawa Gudali. La saison a affecté significativement ( $p$ $<0,05)$ les paramètres thermorégulateurs mesurés sauf $(p>0,05)$ la température rectale. Les valeurs les plus élevées enregistrées de la fréquence respiratoire étaient (27,85 battements / min), la fréquence cardiaque $(27,62$ respirations / min) et le 'HTC' $(2,19)$ étaient à la fin de la saison sèche.L'effet de l'interaction entre la race et la saison sur les paramètres thermorégulateurs était significativement affecté $(p<0,05)$ tous les paramètres thermorégulateurs mesurés. Il a été conclu que les races Bokoloji et Bunaji de bovins indigènes sont plus réactives au stress thermique que Rahaji et Adamawa Gudali, même si cela peut varier avec les saisons de l'année, comme le montre l'interaction entre la race et la saison dans cette étude.

Mots-clés : race, thermorégulation, indigène, bétail 


\section{Breed and seasonal variation in thermoregulatory paramters}

\section{Introduction}

Tropical cattle are known for their ability to tolerate heat while maintaining standards of milk yield, reproduction, and disease resistance (Atrian and Aghdam, 2012). Thermo-tolerance in cattle is one of the desired adaptive ability of tropical cattle. Cattle demonstrate certain physiological responses when under heat stress. It was reported that any change in the environmental conditions, as is the case during heat stress, threatens the normal metabolic balance and usually produces a positive feedback once the temperature is above the upper critical temperature (UCT: 25-26 ${ }^{\circ} \mathrm{C}$ ) (Hayes et al., 2009; Atrian and Aghdam, 2012). Many indices have been proposed to measure the level of heat stress, however, their application is restricted to Temperature Humidity Index (THI) which had been used to integrate environmental temperature and relative humidity (Armstrong, 1994; Thatcher et al., 2010). It has also been considered to be a reliable indicator of heat stress in cattle (Dikmen and Hansen, 2009). Animals can often endure higher temperatures if humidity is low, and the risk for heat stress increases dramatically as humidity increases, even at lower ambient temperatures (Dikmen and Hansen, 2009). THI has been categorized into four major classification; THI over 64 (minimal heat stress), THI over 72 (moderate heat stress), and THI $\geq 76$ (maximal heat stress) and THI of 84 or more, death occurs (Igono et al., 1992; West, 2003).

Some physiological traits are related to the ability of the animal to cope with heat stress (Garner et al., 2016). For example, sweating rate, rectal temperature and respiration rate increase when animals are exposed to warm environment (Garner et al., 2016; Rashamol et al., 2018). Inclusion of these heat tolerance indicator traits in large-scale phenotype recording systems for selecting thermo-tolerant animals appears rather problematic in terms of logistics and costs (Nguyen et al., 2016). Lactating cows have greater tendency to have heat production because of the milk synthesis as compared to dry cows (Isaksson, 2017). Rectal temperature, respiratory rate, pulse rate and heart rate have been used as a reliable indicators of short time physical stress in animals (Ayo et al., 1998; Kubkomawa et al., 2015).

Respiration rate which is the intake of oxygen and elimination of carbon dioxide under thermo-neutral condition that leads to evaporation and dissipation of moisture from the respiratory tract to maintain thermal balance (da Silva et al., 2017; Rashamol et al., 2018) has been considered as one of the critical biomarkers for determining heat stress in farm animals. Rashamol et al. (2018) also opined that RR may act as an early signal of heat stress condition in livestock. High producing cattle have been reported to suffer more from heat stress than low producing cattle (West, 2002; Nayak et al., 2018). Heattolerant cows, ranked according to a genomic breeding value of heat tolerance based on milk yield, showed lower values of physiological indicators (core body temperature, rectal and intra-vaginal temperature) than heat-sensitive cows (Macciotta et al., 2016). Heat stress causes changes in phenotypic and genotypic traits in livestock and is quantified by the measurement of physiological responses such as respiration rate (RR), rectal temperature(RT), skin temperature(ST), pulse rate (PR) and sweating rate (SR) (Rashamol et al., 2018). Among the physiological parameters RR, RT and ST are identified as the biomarkers for quantifying the heat stress impact on livestock (Shaji et al., 2016). Some physiological parameters were reported to be associated with thermo-tolerance in Indian Thartarker cattle, Angus cattle, Holstein-Friesian cross bred and Deoni 
cattle raised in India and Sahiwal cows in India. But there is dearth of information on the thermos-tolerant ability of the Nigerian indigenous cattle. Therefore, this paper seeks to present breed variation in thermotolerance of four selected Nigerian indigenous cattle using physiological biomarkers.

\section{Materials and methods Studylocation}

The study was conducted in some selected dairy herds in Mubi, Gombi and Song Local Government Areas of Adamawa State. Adamawa State is located at an altitude of 200 to 300 metres, between latitude $9^{\circ} 20^{\prime}$ and $9^{\circ} 33^{\prime} \mathrm{N}$ and longitude $12^{\circ} 30^{\prime}$ and $12^{\circ} 50^{\prime}$ E. It is bordered by Borno State to the North West, Gombe to the West and Taraba to the South West and has an Eastern border with Cameroun Republic. It has average daily minimum and maximum temperatures of 23.2 and $35.2^{\circ} \mathrm{C}$ respectively. The average annual rainfall is 718.1 millimetres and relative humidity, $44.2 \%$. It occupies an area of $39,742.12$ square kilometres. It is generally characterized by many rivers; the major one being the River Benue whose source is from the highlands of the Cameroun and flows southwards to join the River Niger. The predominant climate is Sahel, rainy season last for only three to four months (June-September). The rest of the year is cold-dry characterized by a lack of heat stress conditions with a relatively cool, dry with continental air mass that originates from the Sahara Desert associated with dry, cold and dusty NorthEast trades (harmattan) and hot-dry (March-May) characterized by high ambient temperature, relative humidity and heat stress conditions (National Bureau of Statistics, 2010; Ovimaps, 2018).

Sources of experimental animals and management

Eighty (80) clinically healthy dairy cows made up of twenty (20) each of Adamawa
Gudali, Rahaji, Bokoloji and Bunaji of similar ages (3-5) and within their $1^{\text {st }}$ and $2^{\text {nd }}$ parity in selected Farms in Adamawa State were used for the experiment. The experiment spanned for two seasons of the year. These seasons were; late rainy (August-October and late dry (FebruaryApril). The animals that used were in their early lactation stage (1-60) days.

\section{Thermoregulatory data collection}

Rectal temperature (RT): This was taken using a digital thermometer. The sensory tip was disinfected and inserted into the rectum at the display of $\mathrm{L}^{0} \mathrm{C}$ by a thermometer (which is an indication that the thermometer was set for temperature reading) and was removed by the sound of alarm signal. It was recorded in ${ }^{0} \mathrm{C}$.

Respiratory rate (RR): This was determined by counting the number of flank movements per minute as reported by Aritonang et al. (2017)

Pulse rate: this was taken by using placing a stethoscope. It was measured by placing the fingertips on the femoral arteries of the hind limb for 1 minute. It was recorded in beats/minute

Heat Tolerance Coefficient (HTC): HTC was calculated based on heat tolerance index developed by Benezra (1954). The formula is based on both respiration rate and rectal temperature.

HTC: RR/23+RT/38.33

The above measurements were taken monthly for the period of three (3) months in each season (August - October, 2019 and February-April, 2020) given a total of 640 observations.

\section{Data analyses}

Statistical model: The statistical model for the analysis is as given below;

$\mathrm{Y}_{\mathrm{ijk}}=\mu+\mathrm{B}_{\mathrm{i}}+\mathrm{S}_{\mathrm{j}}+\left(\mathrm{B}_{\mathrm{i}} \mathrm{x} \mathrm{S}_{\mathrm{j}}\right)+\mathrm{e}_{\mathrm{ijk}}$

Where; $\mu=$ general mean, $B_{i}=i^{\text {th }}$ fixed effect of breed $(B=1,2,3,4) ; S_{j}=j^{\text {th }}$ fixed effect of season $(1,2) ;\left(B_{\mathrm{i}} \times \mathrm{S}_{\mathrm{j}}\right)=$ Interaction 


\section{Breed and seasonal variation in thermoregulatory paramters}

between Breed and season; $\mathrm{e}_{\mathrm{ijk}}=$ residual error.

\section{Statistical analysis}

The data collected on thermoregulatory parameters was subjected to analysis of variance (ANOVA) using General Linear Model of (SAS) (2002) while significant differences were separated using Duncan Multiple Range test (Duncan, 1955). The relationships among thermoregulatory parameters were determined using the Pearson product moment correlation of the same software.

\section{Results and discussion}

Table 1 shows the effect of breed variation on thermoregulatory parameters of four selected indigenous breeds of cattle. There were significant $(p<0.05)$ effect of breed on the parameters measured except for rectal temperature $(p<0.05)$. Bokoloji recorded the highest in respiratory rate $(21.80$ beats/minutes) and Heat Tolerance Coefficient (1.91) while the highest recorded value for pulse rate $(22.10$ beats/minutes) was in in Bunaji. The Coefficient of Variation (CV) of thermoregulatory measured ranged from 3.05 to 23.89 . The most variable parameter was Pulse rate (23.89) of Rahaji while the least variable was in rectal temperature 93.05) of Adamawa Gudali. In this study, Bokoloji recorded the highest value of RR against its counterparts the late rainy season. This implied that Bunaji breed was the most uncomfortable in the late rainy season of study since a marked increase in RR from the normal level ( 30 beats per minutes) is an indication of unbalanced homeostasis and that the animal is trying to dissipate heat load from the body (HTC et al., 2007). Breed variation in RR was also reported by Sailo et al. (2017), the RR were reported to be 15.738 in Sahiwal and 15.779 breaths/ minute in Karan Fries cattle during winter. In another study, Valente et al
(2015) reported a higher RR in Angus cattle $\left(104\right.$ breaths/ minute at $\left.37^{\circ} \mathrm{C}\right)$ during a heat stressed condition. Correa-Calderon et al. (2004) observed a higher RR in heatstressed Brown Swiss and Holstein cows under a cooling system than other breeds. Indu and Pareek (2015) opined that higher RR than 80 breath/minute was found to be indicator of higher quantum of heat stress in farm animals. Contrary to this study, Sailo et al. (2017) reported a significant breed variation within different seasons. Variation between this study and other studies could be as a result of differences in season, location and breeds used. Other factors that affect the physiological responses in cattle include cow's age, parity, the production type, housing system, how often the cows are milked and which milking system the producers use (Smith and Risco, 2005; Isaksson, 2017).

Heat tolerance coefficient measures the adaptability of an animal during heat stress. Hence lower HTC may indicate an improved thermo-tolerance which had been useful in genetic improvement in cattle (Kumar et al., 2017). From this study therefore, Rahaji is the most adaptable breed in the studied area. The high HTC recorded in Bunaji and Bokoloji could be attributed to the fact that high producing cattle suffer most from heat stress absorbed from the environment due to their inherently higher levels of productivity (Blackshaw and Blackshaw, 1994; West, 1994; Dikmen and Hansen, 2009; Thatcher et al., 2010). The effect of breed on thermoregulatory parameters of the selected indigenous breeds of cattle in the late dry season. Breed affected $(p<0.05)$ the parameters measured except HTC $(\mathrm{p}>0.05)$. Adamawa Gudali recorded the highest value of rectal temperature (38.15 while Rahaji recorded the lowest (36.80). Rahaji recorded the highest respiratory rate (31.09) while Adaamwa Gudali recorded the least (24.15). Adamawa Gudali 


\section{Abbaya, Adedibu, Kabir and Iyiola-Tunji}

recorded the highest value of pulse rate (31.30) while Bokoloji recorded the least (21.80). The CV of the thermoregulatory parameters measured ranged from 1.21 to 43.98. The highest recorded CV was HTC of Bunaji while the least was in HTC of Rahaji.

Breed variation was also reported in physiological parameters of indigenous breeds of cattle in Indonesia during the dry season with Bali breed recording higher rectal temperature while Ongole breed recorded the highest respiratory rate (Aritonang et al., 2017). Saiya (2012) also reported that Bali cattle had better thermoregulatory tendency than Ongole cattle breed on the hot climatic condition of Indonesia. Gaughan et al. (1999) also reported that Zebu cattle (B. indicus) had better body temperature regulation than the Taurine cattle (B. taurus) in tropical climatic conditions in India. Rectal temperature and respiratory rate are the major indicators of heat stress in animals (Gaughan et al., 2012; Aritonang et al., 2017). Adamawa Gudali in this study seems to be more thermally stable than its other indigenous counterparts. Respiratory rate is the most sensitive cardinal physiological variable to heat stress and the at the same time the most useful animal based indicators of heat stress in livestock (Berman et al., 1985; Gaughan et al., 2002; Yaqub et al., 2017; Habibu et al., 2019) as change in respiratory rate precedes other cardinal physiological variables during heat stress (Jian et al., 2015; Dalcin et al., 2016; Singh et al., 2018). Differences in thermoregulatory parameters could be as a result of differences in genes that can affect colour characteristics and structure of the cattle's body (Aritonang et al., 2017). Among other factors that affect physiological responses in cattle, age, stage of lactation, physiological status of an animal, exercise, excitement, fullness of the digestive tract, the time of the day and environmental surrounding can also breed about variation in physiological responses in responses to heat stress in livestock (Prendiville et al., 2002; Kubkomawa et al., 2015; Macias-Cruz et al., 2018; Habibu et al., 2019).

The pooled breed variation in thermoregulatory parameters of some selected indigenous breeds of cattle in Nigeria is shown in Table 1. Breed influenced $(p<0.05)$ all the parameters measured. Bunaji recorded the highest rectal temperature $\left(37.92^{\circ} \mathrm{C}\right)$ in all the seasons of measurement. Respiratory rate and Heat tolerance coefficient were highest in Bokoloji while the least were in Bunaji and Adamawa Gudali. The $\mathrm{CV}$ ranged from 1.92-35.66. The most variable parameter was pulse rate (35.66) in Rahaji while the least variable was rectal temperature in Bunaji (1.92). Different breeds of cattle respond to environmental conditions differently. Some are more sensitive to environments than others (Thatcher et al., 2010; Adedibu et al., 2015). Variation in physiological adaptability was reported to be established between indigenous, cross bred and pure bred animals (Rashamol et al., 2018). Dikmen et al. (2012) reported that $13-17 \%$ of the differences in rectal temperature in cows during heat stress is as a result of genetic makeup of the cows. The high value of HTC in Bokoloji and Bunaji concurred with the repot of Pragna et al. (2016) who opined that high yielding cows are more susceptible to heat stress than low yielding cows. Dikmen et al. (2012) estimated that 13 to $17 \%$ of the variation in rectal temperature in cows during heat stress is due to genetic differences. Sailo et al. (2017) ran an experiment on Sahiwal and Karan Fries cattle and reported RT $\left({ }^{\circ} \mathrm{C}\right)$ of $37.300,38.178$ and 38.810 , while in Karan Fries 37.492, 38.398 and 39.186 during winter, spring and summer respectively. Physiological adaptive 


\section{Breed and seasonal variation in thermoregulatory paramters}

mechanisms vary between species and within specie breeds (Rashamol et al., 2018). Aside other factors considered in this study, the colour of the animal also affect adaptability to heat stress. Animals with black hides have been reported to be affected significantly suffer heat stress than those with white hides $(89 \%$ for black hides and $55 \%$ for white (Gebremedhin et al., 2011). Dark-hided cattle have been reported to be $25 \%$ more stressed at temperatures above 25 degrees Celsius when compared to light-hided cattle (Brown-Brandl et al., 2006). Brown-Brandl et al. (2006) also identified other risk factors for heat stress aside from hide color, including history of respiratory pneumonia, level of fatness, and temperament. BrownBrandl et al. (2006) also established that excitable animals were $3.2 \%$ more stressed than their calm counterparts.

Table 2 : Breed variation (Mean $\pm \mathrm{SE}$ ) in thermoregulatory parameters of some selected indigenous breeds of cattle in Nigeria in the late rainy and late dry seasons

\begin{tabular}{|c|c|c|c|c|c|c|c|c|c|}
\hline Season & Parameter & A Gudali & $\mathrm{CV}$ & Rahaji & $\mathrm{CV}$ & Bunaji & $\mathrm{CV}$ & Bokoloji & $\mathrm{CV}$ \\
\hline \multicolumn{10}{|l|}{$\begin{array}{l}\text { Late } \\
\text { rainy }\end{array}$} \\
\hline & $\mathrm{RT}\left({ }^{\circ} \mathrm{C}\right)$ & $36.80 \pm 0.25$ & 3.05 & $36.98 \pm 0.30$ & 3.61 & $36.96 \pm 0.27$ & 3.23 & $37.84 \pm 0.15$ & 1.74 \\
\hline & RR (beat/min.) & $19.70 \pm 0.73^{\mathrm{ab}}$ & 16.64 & $18.00 \pm 073^{b}$ & 18.20 & $21.80 \pm 0.61^{\mathrm{a}}$ & 14.85 & $18.30 \pm 0.74^{b}$ & 15.05 \\
\hline & PR(breaths/min) & $16.80 \pm 0.84^{b}$ & 22.49 & $16.90 \pm 0.90 \mathrm{~b}$ & 23.89 & $16.10 \pm 0.50^{b}$ & 17.21 & $22.10 \pm 0.62^{\mathrm{a}}$ & 10.05 \\
\hline & HTC & $1.82 \pm 0.03^{\mathrm{ab}}$ & 8.35 & $1.75 \pm 0.27^{\mathrm{b}}$ & 7.10 & $1.91 \pm 0.03^{\mathrm{a}}$ & 8.02 & $1.78 \pm 0.03^{\mathrm{ab}}$ & 7.11 \\
\hline \multicolumn{10}{|l|}{$\begin{array}{l}\text { Late } \\
\text { dry }\end{array}$} \\
\hline & $\mathrm{RT}\left({ }^{\circ} \mathrm{C}\right)$ & $38.15 \pm 0.21^{\mathrm{a}}$ & 1.75 & $36.80 \pm 0.09^{c}$ & 0.77 & $37.63 \pm 0.34^{\mathrm{ab}}$ & 2.86 & $37.27 \pm 0.22^{b c}$ & 1.94 \\
\hline & RR (beat/min.) & $24.20 \pm 1.27^{\mathrm{c}}$ & 16.62 & $31.09 \pm 2.00^{\mathrm{a}}$ & 20.36 & $30.30 \pm 1.56^{\mathrm{ab}}$ & 16.32 & $25.80 \pm 1.37^{\mathrm{bc}}$ & 16.83 \\
\hline & PR(breaths/min) & $31.30 \pm 0.81^{\mathrm{a}}$ & 8.18 & $31.49 \pm 0.45^{\mathrm{a}}$ & 4.50 & $21.80 \pm 1.47^{\mathrm{c}}$ & 21.28 & $25.87 \pm 1.76^{b}$ & 21.53 \\
\hline & HTI & $11.70 \pm 0.07$ & 1.86 & $11.40 \pm 0.04$ & 1.21 & $10.84 \pm 0.05$ & 1.45 & $10.36 \pm 1.44$ & 43.98 \\
\hline \multicolumn{10}{|l|}{ Pooled } \\
\hline & $\mathrm{RT}\left({ }^{\circ} \mathrm{C}\right)$ & $37.25 \pm 1.17^{\mathrm{ab}}$ & 3.13 & $36.92 \pm 1.10^{\mathrm{b}}$ & 3.97 & $37.65 \pm 0.72^{\mathrm{a}}$ & 1.92 & $37.18 \pm 1.18^{\mathrm{ab}}$ & 3.17 \\
\hline & RR (beat/min.) & $21.20 \pm 4.09^{\mathrm{b}}$ & 19.29 & $22.36 \pm 7.67^{\mathrm{ab}}$ & 34.31 & $20.80 \pm 4.87^{b}$ & 23.43 & $24.63 \pm 4.37^{\mathrm{a}}$ & 22.63 \\
\hline & PR(breaths/min) & $21.63 \pm 7.73^{\mathrm{a}}$ & 35.72 & $21.76 \pm 7.76^{\mathrm{a}}$ & 35.66 & $23.36 \pm 4.02^{\mathrm{a}}$ & 17.20 & $18.00 \pm 4.37^{b}$ & 24.33 \\
\hline & HTC & $1.89 \pm 0.19^{\mathrm{b}}$ & 10.20 & $1.94 \pm 0.33^{\mathrm{ab}}$ & 16.88 & $1.89 \pm 0.21^{\mathrm{b}}$ & 11.08 & $2.04 \pm 0.25^{\mathrm{a}}$ & 12.42 \\
\hline
\end{tabular}

S.E $=$ Standard error; $\mathrm{C} . \mathrm{V}=$ Coefficient of variation; $\mathrm{ab}=$ means with different superscripts within the rows are significantly different at 5\% RT = Rectal temperature; RR = Respiratory rate; PR = Pulse rate; HTC = Heat Tolerant Coefficient.

Table 2 shows the effect of season on thermoregulatory parameters of indigenous breeds of cattle. Season significantly $(\mathrm{p}<0.05)$ affected thermoregulatory parameters measured except $(\mathrm{p}>0.05)$ rectal temperature. The highest recorded values of respiratory rate and $\mathrm{HTC}$ were in the late dry season while the least pulse rate and HTC were in the late rainy season. The $\mathrm{CV}$ of the thermoregulatory parameters measured ranged from 3.12-22.41 in the late rainy season and from 2.33-20.22 in the late dry season. The most variable parameter in the late rainy and late dry seasons were pulse rate $(22.41 \mathrm{beat} / \mathrm{min})$ and respiratory rate (20.22 breaths/min) respectively. The least variable in both seasons was rectal temperature. Season has been reported to be one of the factors that affect physiological parameters in dairy animals (Kumar et al., 2017). Seasonal summer reductions in productive and reproductive performance of lactating cows have been reported to associate with reduced thermoregulatory ability of lactating dairy cows, partially due to 


\section{Abbaya, Adedibu, Kabir and Iyiola-Tunji}

intensive genetic selection for high milk production (Al-Katanani et al., 1999; Aguilar et al., 2009; Renaudeau et al., 2012). Whereas, rectal temperature measures serve as the direct indicator of the thermal state of an animal, skin temperature, respiratory rate, pulse rate and heart rate reflect the thermolytic state of the animal (Kabuga, 1992; Jian et al., 2015; Habibu et al., 2017; Habibu et al., 2019). Season was reported to influence physiological parameters (RT, RR and PR) in Hariana and Sahiwal breeds of cattle with summer season recording the highest values for all the parameters measured (Kumar et al., 2017). Respiratory rate was reported to rise in hot dry season in exotic dairy animals (Raymond, 2017). Tuner et al. (1992) recorded 16breath/min. less in a cooled group than in un-cooled groups of dairy cows. Habeeb et al. (1997) and Marai et al. (2001) also reported an increase in thermoregulatory parameters in the hot dry season. Respiratory rate was reported to be the most sensitive cardinal and most useful animal- based physiological indicator of heat stress in livestock (Gaughan et al., 2000; Yaqub et al., 2017). This is because changes in RR always precede changes in the other cardinal physiological variables such as RT, sweating and pulse rate (Jian et al., 2015; Dalcin et al., 2016; Singh et al., 2018). The changes in the RR are indicators of adaptive response of the animal to maintain homoeo-thermic balance (Kumar et al., 2017). Also, increase in PR causes an increases in the blood flow to the surface and thereby facilitating heat loss (Marai et al., 2001). Sailo et al (2017) also reported an increase in RR of 15.74, 18.16 and 29.82 in Sahiwal and 15.78, 22.98 and 47.30 breaths/minute in Karan Fries cattle during the winter, spring and summer seasons, respectively. Shaji et al (2016) also reported an increase in PR in Osmanabadi goats exposed to heat stress indicating its role in assessing heat loads in animals. Significant higher physiological parameters (RR and PR) in the present experiment during the late dry season may be due to the high ambient temperature and which must have exceeded the comfort zone of the animals, resulting in the imbalance in the heat energy produced and dissipated (Singh et al., 2014; kumar et al., 2017). Deviation from the normal rectal temperature has been considered as an index of discomfort. It has been considered as an index of body temperature even though considerable variations in various body parts in core body temperature exist at different times of the day (Singh et al., 2014). The non-significant effect of season on RT in this study concur with the report of Blackshaw and Blackshaw (1994) who also reported an increase in heart rate and respiratory rate but not rectal temperature during different seasons. Contrary to the findings in this study however, Kumar et al. (2017) reported a significant increase in the RT of Hariana and Sahiwal breeds of cattle as season changes. Significant increase in RT was also recorded in buffalo calves and cattle exposed to heat as compared to those under a comfortable condition (Korde et al., 2007; Alok et al., 2014; Singh et al., 2014; Raymond, 2017). The observed differences in thermoregulatory parameters between the late rainy and late dry seasons in this study could be due to stress-induced hyperthermia (Piccione et al., 2007; Raymond, 2017) and also to the fact that several factors affect the adaptability ability of animals. These includes the animal's morphology, physiology, biochemistry and behavior that help them to survive specific environments (Das et al., 2016; Rashamol et al., 2018). The external condition of the animal is made up of the ambient temperature, relative humidity, solar radiation and wind (Pragna et al., 2016). It was reported that elevated environmental 


\section{Breed and seasonal variation in thermoregulatory paramters}

temperature, solar radiation, and relative humidity leads to hyperthermia or heat stress (Collier et al., 2006) which in return affects milk production (Prasad et al., 2012). Key et al. (2014) showed that the impact of environmental temperature on livestock is one of the four major ways that livestock production could be impacted due to climate change by affecting animal health, reproduction and animal products (meat and milk).

Table 2: Effect of season (Mean \pm SE) on thermoregulatory parameters of some selec ted breeds of cattle in Nigeria

\begin{tabular}{lllll}
\hline Traits & Late Wet & CV & Late Dry & CV \\
\hline RT $\left({ }^{\circ} \mathrm{C}\right)$ & $37.15 \pm 0.13$ & 3.12 & $37.64 \pm 0.14$ & 2.33 \\
RR (beat/min.) & $19.45 \pm 0.38^{\mathrm{b}}$ & 17.66 & $27.85 \pm 0.89^{\mathrm{a}}$ & 20.22 \\
PR(breaths/min) & $17.98 \pm 0.45^{\mathrm{b}}$ & 22.41 & $27.62 \pm 0.88^{\mathrm{a}}$ & 20.12 \\
HTI & $1.81 \pm 0.02^{\mathrm{b}}$ & 8.28 & $2.19 \pm 0.04^{\mathrm{a}}$ & 11.01 \\
\hline
\end{tabular}

S.E = Standard error; C. V = Coefficient of variation; $a b=$ means with different superscripts within the rows are significantly different at 5\%; RT $=$ Rectal temperature; $\mathrm{RR}=$ Respiratory rate; $\mathrm{PR}=$ Pulse rate; $\mathrm{HTC}=$ Heat Tolerant Coefficient.

The effect of interaction between breed and season on thermoregulatory parameters is shown in Table 3. There was a significant effect $(p<0.05)$ of interaction between breed and season on all the thermoregulatory parameters measured. The highest recorded rectal temperature was recorded in B1S2 (38.15) while the least were in B1S1 (36.80), B2S1 (36.98), B3S1 (37.96) and B4S2 (37.27). The highest recorded values of respiratory rate were in B2S2 (31.09) and B3S2 (30.30) while the least recorded values of respiratory rate were in $\mathrm{B} 2 \mathrm{~S} 1$ and $\mathrm{B} 4 \mathrm{~S} 1$ $(18.00,18.30)$, respectively. The highest recorded values of pulse rate were in B1S2 and B2S2 $(31.30,31.49)$ while the lowest recorded values were in $\mathrm{B} 1 \mathrm{~S} 1, \mathrm{~B} 2 \mathrm{~S} 1$ and B3S2 (16.80, 16.90 and 16.10), respectively. Finally, the highest recorded values of Heat Coefficient index were in $\mathrm{B} 2 \mathrm{~S} 2$ and B3S2 (2.31 and 2.30) while the lowest values were in 1S1, B2S1 and B4S1 $(1.82,1.75$ and 1.78$)$, respectively.

Table 2: Interaction between Season and Breed on Thermoregulatory Response of selected

\begin{tabular}{ccccc}
\multicolumn{2}{c}{ indigenous breeds of cattle in Nigeria } \\
\hline $\begin{array}{c}\text { BREED } \\
\text { X }\end{array}$ & RT & RR & PR & HTC \\
SEASON & \multicolumn{1}{l}{} \\
\hline $\mathrm{B}_{1} \mathrm{~S}_{1}$ & $36.80^{\mathrm{b}}$ & $19.70^{\mathrm{cd}}$ & $16.80^{\mathrm{d}}$ & $1.82^{\mathrm{c}}$ \\
$\mathrm{B}_{1} \mathrm{~S}_{2}$ & $38.15^{\mathrm{a}}$ & $24.20^{\mathrm{b}}$ & $31.30^{\mathrm{a}}$ & $2.05^{\mathrm{b}}$ \\
$\mathrm{B}_{2} \mathrm{~S}_{1}$ & $36.98^{\mathrm{b}}$ & $18.00^{\mathrm{d}}$ & $16.90^{\mathrm{d}}$ & $1.75^{\mathrm{c}}$ \\
$\mathrm{B}_{2} \mathrm{~S}_{2}$ & $36.80^{\mathrm{b}}$ & $31.09^{\mathrm{a}}$ & $31.49^{\mathrm{a}}$ & $2.31^{\mathrm{a}}$ \\
$\mathrm{B}_{3} \mathrm{~S}_{1}$ & $36.96^{\mathrm{b}}$ & $21.80^{\mathrm{c}}$ & $16.10^{\mathrm{d}}$ & $1.91^{\mathrm{bc}}$ \\
$\mathrm{B}_{3} \mathrm{~S}_{2}$ & $37.63^{\mathrm{ab}}$ & $30.30^{\mathrm{a}}$ & $21.80^{\mathrm{c}}$ & $2.30^{\mathrm{a}}$ \\
$\mathrm{B}_{4} \mathrm{~S}_{1}$ & $37.84^{\mathrm{ab}}$ & $18.30^{\mathrm{d}}$ & $22.10^{\mathrm{c}}$ & $1.78^{\mathrm{c}}$ \\
$\mathrm{B}_{4} \mathrm{~S}_{2}$ & $37.27^{\mathrm{b}}$ & $25.80^{\mathrm{b}}$ & $25.89^{\mathrm{b}}$ & $2.09^{\mathrm{b}}$ \\
$\mathrm{SEM}_{\mathrm{REM}}$ & 0.33 & 1.13 & 0.95 & 0.09 \\
\hline
\end{tabular}

$\mathrm{RT}=$ Rectal temperature; $\mathrm{RR}=$ Respiratory rate; $\mathrm{PR}=$ Pulse rate; $\quad \mathrm{HTC}=$ Heat Tolerant Index, $\mathrm{B}{ }_{1} \mathrm{~S}_{1}=$ Adamawa Gudali $x$ late rainy season, $\mathrm{B}_{1} \mathrm{~S}_{1}=$ Adamawa Gudali $\mathrm{x}$ late dry season, $\mathrm{B}_{2} \mathrm{~S}_{1}=$ Rahaji $\mathrm{x}$ late rainy season, $\mathrm{B}_{2} \mathrm{~S}_{2}=$ Rahaji $\mathrm{x}$ late dry season, $\mathrm{BS}_{1}=$ Bokoloji $\mathrm{x}$ late rainy season, $\mathrm{BS}_{2}=$ Bokoloji $\mathrm{x}$ late dry season, $\mathrm{B}_{4} \mathrm{~S}_{1}=$ Bunaji $\mathrm{x}$ late rainy season, $\mathrm{B}_{4} \mathrm{~S}_{2}=$ Bunaji $\mathrm{x}$ late dry season, abcd= means with different superscripts within the rows are significantly different at $5 \%$. 
Selection for milk yield reduces the thermoregulation ability during heat stress which magnifies the seasonal depression in productivity caused by climatic stress (A1Katanani et al., 1999; Chaiyabutr et al., 2011) The zebu (Bos indicus) breeds are reported to have higher degree of thermotolerance compared with temperate (Bos taurus) breeds because of lower metabolic rate and Adamawa Gudali in the late dry season recorded the highest value of rectal temperature. This concurred with the report of Correa-Calderon et al. (2004) and Raymond (2017) who reported that Friesian and Brown Swiss had the highest recorded rectal temperature in the hot dry season. Whereas, rectal temperature measures serve as the direct indicator of the thermal state of an animal, skin temperature, respiratory rate, pulse rate and heart rate reflect the thermolytic state of the animal (Kabuga, 1992; Jian et al., 2015; Habibu et al., 2017; Habibu et al., 2019). Season was reported to influence physiological parameters (RT, RR and PR) in Hariana and Sahiwal breeds of cattle with summer season recording the highest values for all the parameters measured (Kumar et al., 2017). Respiratory rate was reported to rise in hot dry season in exotic dairy animals (Raymond, 2017) Breed variation was also reported in physiological parameters of indigenous breeds of cattle in Indonesia during the dry season with Bali breed recording higher rectal temperature while Ongole breed recorded the highest respiratory rate (Aritonang et al., 2017). Saiya (2012) also reported that Bali cattle had better thermoregulatory tendency than Ongole cattle breed on the hot climatic condition of Indonesia. Gaughan et al. (1999) also reported that Zebu cattle (B. indicus) had better body temperature regulation than the Taurine cattle ( $B$. taurus) in tropical climatic conditions in India.

\section{Conclusion}

It was concluded that Bokoloji and Bunaji breeds of indigenous cattle are more reactive to heat stress than Rahaji and Adamawa Gudali as they recorded the highest heat tolerance coefficient, though this could vary with seasons of the year as seen in the interaction between breed and season in this study. Aso, most thermoregulatory parameters were highest in late dry season and therefore making the late dry season the most likely season the cows will react more to heat stress in Nigerian.

\section{References}

Adedibu, I. I., Barje, P. P., Mohammed, A., Kabir, M. and Akinsola, $O$. M. 2015. Comparison of Friesian $x$ Bunaji crosses for milk production traits in the era of climate change. Journal of Agriculture and Agricultural Technology, 60(1): 47-52.

Aguilar, I., Misztal, I. and Tsuruta, S. 2009. Genetic components of heat stress for dairy cattle with multiple lactations. Journal of Dairy Science, 92: 5702-5711.

Al-Katanani, Y. M., Webb, D. W. and Hansen, P. J. 1999. Factors affecting seasonal variation in 90day non return rate to first service in lactating Holstein cows in a hot climate. Journal of Dairy Science, 82(12): 2611-2616.

Alok K., Wankar., Gyanendra Singh, A. K. and Brijes Yada. 2014. Thermoregulatory and adaptive responses of adult buffaloes during hyperthermia: physiological, behavioural, and metabolic approach. Veterinary world, 7 (10): 825-830.

Aritonang, S. B., Yuniati, R., 
A b i n a w a n to, M. a nd Bowolaksono, A. 2017. Physiology Response of the Indigenous Cattle Breeds to the Environment in West Sumbawa, Indonesia. AIP Conference Proceedings 1862, 030098. doi: 10.1063/1.4991202.

Atrian, P. H. and Aghdam, S. 2012. Heat Stress in Dairy Cows (A Review). Research in Zoology, 2(4): 31-37.

Ayo, J. O, Oladele, S. B. Fayomi, A., Jumbo, S. D. and Hambolu, J. O. 1998. Body temperature, respiration and heart rates in the Red Sokoto goat during harmattan season. Bulletin of Animal and Health Production in Africa, 46: 161-166.

Benezra, M. V. 1954. A New Index for Measures the Adaptability of Cattle to Tropical condition. Journal of Animal Science, 13:1915.

Berman, A., Folman, Y., Kaim, M., M a m e n, M ., H e rz, Z ., Wolfenson, D., Ariel, A. and Graber, Y. 1985. Upper critical temperatures and forced ventilation effect for high yielding dairy cows in subtropical climate. Journal of Dairy Science, 68:14881495.

Blackshaw, J. K. and Blackshaw, A. W. 1994. Heat stress in cattle and the effect of shade on production and behavior: A review. Australian Journal of Experimental Agriculture, 34:285-295.

Brown-Brandl, T. M., Eigenberg, R. A. and Nienaber, J. A. 2006. Heat stress risk factors of feedlot heifers. Livestock Science, 105: (1-3): 5768 .

$\mathrm{D}$ o $\mathrm{i}$ : 10.1016/j.livsci.2006.04.025.

Collier, R. J., Dahl, G. E., Van-Baale, M. J. 2006. Major advances associated with environmental effects on dairy cattle. Journal of Dairy Science, 89:1244-1253.

Correa-Calderon, A., Armstrong, D., Ray, D., DeNise, S., Enns, M. and Howison, C. 2004. Thermoregulatory responses of Holstein and Brown Swiss heat-stressed dairy cows to two different cooling systems. International Journal of Biometeorology, 48:142-148.

Dalcin, V.C., Fischer, V., dos Santos Daltro, D., Alfonzo, E. P. M., Stumpf, M.T., Kolling, G.J., da Silva, M.V.G.B. and McManus, C. 2016. Physiological parameters for thermal stress in dairy cattle Revista Brasileira de Zootecnia. Revista Brasileira de Zootecnia, 45: 458-465.

Da Silva, W. E., Leite, J. H. G. M., de Sousa, J. E. R., Costa, W. P., da Silva, W. S. T., Guilhermino, M.M. and Façanha, D. A. E. 2017. Daily rhythmicity of the thermoregulatory responses of locally adapted Brazilian sheep in a s e miarid environment. International Journal of Biometeorology, 61:1221-1231.

Das, R., Sailo, L., Verma, N., Bharti, P., Saikia, J., Imtiwati, L. and Kumar, R. 2016. Impact of heat stress on health and performance of dairy animals: A review. Veterinary World, 9:260-268.

Dikmen, S. and Hansen, P. J. 2009. Is the temperature-humidity index the best indicator of heat stress in lactating dairy cows in a subtropical environment? Journal of Dairy Science, 92:109-116.

Dikmen, S., Cole, J. B., Null, D. J. and Hansen, P. J. 2012. Heritability of rectal temperature and genetic correlations with production and 
reproduction traits in dairy cattle. Journal of Dairy Science, 95:3401-3405.

Duncan, D. B. 1955. Multiple range and multiple F-test. Biometrics, 11: 1 14.

Garner, J. B., Douglas, M. L., Williams, S. R. O., Wales, W. J., Marett, L. C., Nguyen, T. T. T., Reich, C. M. and Hayes, B. J. 2016. Genomic selection improves heat tolerance in dairy cattle. Scientific Reports, 6 ( 1 ) : $1-9$; https://doi.org/10.1038/srep34114.

Gaughan, J. B. 2002. Respiration Rate and Rectal Temperature Responses of Feedlot Cattle in Dynamic, Thermally Challenging Environments. The University of Queensland Gatton: Queensland, Australia.

Gaughan, J. B., Mader, T. L. and Gebremedhin, K. G. 2012. "Rethinking Heat Index Tools for Livestock," in Environmental Physiology of Livestock, edited by R. J. Collier and J. L. Collier (John Wiley \& Sons), Hoboken, New Jersey. Pp. 243-265.

Gaughan, J. B., Mader, T. L., Holt, S. M., Josey, M. J. and Rowan, K. J. 1999. Journal of Animal Science, 77: 2398-2405.

Gebremedhin, K. G., Lee, C. N., Hillman, P. E. and Brown-Brandl, T. 2011. Body temperature and behavioral activities of four breeds of heifers in shade and full sun. Applied Engineering in Agriculture, 27: 999-1006.

Habeeb, A. A. M.; Marai, I. F. M. and Owen, J. B. 1997. Genetic improvement of livestock for heat adaptation in hot climates. International Conference of Animal Production and Health,
Zag. Univ., 2-4 Sept., Zag. Egypt

Habibu, B., Kawu, M., Makun, H., Aluwong, T., Yaqub, L., Dzenda, T., Hajarah Bu-harI, H. 2017. Influences of breed, sex and age on seasonal changes in haematological variables of tropical goat kids. Archive of Animal Breeding, 60: 33-42

Habibu, B., Kawu. M. U., Makun, H. J., Aluwong, T. and Yaqub, L. S. 2016. Seasonal variation in body mass index cardinal physiological variables and serum thyroid hormones profiles in relation to susceptibility to thermal stress in goats kids. Small Ruminant Research, 145: 20-27.

Habibu, B., Yaqub, L. S., Dzenda, T. and Kawu. M. U. 2019. Sensitivity, impact and consequences of changes in respiratory rate during thermoregulation in livestock - A REVIEW. Annals of Animal Science, 19 (2): 291-304 DOI: 10.2478/aoas-2019-0002

Hansen, P. J. 2004. Physiological and cellular adaptations of Zebu cattle to thermal stress. Animal Reproductive Science, 82-83: 349360.

Hayes, B. J., Bowman, P. J., Chamberlain, A. J. and Goddard, M. E. 2009. Invited review: Genomic selection in dairy cattle: Progress and challenges. Journal of Dairy Science, 92(2): 433- 443.

Indu, S. and Pareek, A. 2015. A Review: Growth and Physiological Adaptability of Sheep to Heat Stress under Semi-Arid Environment. International Journal of Emerging Trends in Science and Technology, 3(9): $\begin{array}{llllllllll}3 & 8 & 8 & -3 & 1 & 9 & 8\end{array}$ D o i 
10.18535/ijetst/v2i9.09.

Isaksson, J. 2017. Changes in dairy cows' temperature. M. Sc Thesis submitted to the Department of Anatomy, Physiology and Biochemistry, Uppsala. Pp: 1-52.

Jian, W., Ke, Y. and Cheng, L. 2015. Physiological responses and lactation to cutaneous evaporative heat loss in Bos indicus, Bos taurus, and their crossbreds. Asian Australian Journal of Animal Science, 28: 1558.

Kabuga, J. D. 1992. The influence of thermal conditions on rectal temperature, respiration rate and pulse rate of lactating HolsteinFriesian cows in the humid tropics. International Journal of Biometeorology, 36: 146-150.

Korde, J. P., Singh, A. K., Varshney, V.P., and Shuva, D.C. 2007. Effects of long - term heat exposure on adaptive mechanism of blood acid - base in buffalo calves. Asian Australian Journal of Animal Science, 13:329-332.

Kubkomawa, I. H., Emenalom, O. O. and Okoli, I. C. 2015. Body Condition Score, Rectal Temperature, Respiratory, Pulse and Heart Rates of Tropical Indigenous Zebu Cattle: A Review. International Journal of Agriculture Innovations and Research, 4 (3): 448- 454

Kumar, R., Gupta, I. D., Verma, A., Verma, N. and Vineeth, M. R. 2017. Single nucleotide polymorphism in heat Shock protein (HSP) 90AA1 gene and their association with heat tolerance traits in Sahiwal cows. Indian journal of Animal resources, 51: 64- 69

Macciotta, N. P. P., Biffani, S.,
Bernabucci, U., Lacetera, N. Vitali, A. Ajmone-Marsan, P. and Nardone, A. 2016. Derivation and genome-wide association study of a principal component-based measure of heat tolerance in dairy cattle. Journal of Dairy Science, 100:4683-4697.

Macías - Cruz, U., Correa - Calderón, A., Mellado, M., Meza-Herrera, C. A., Aréch-iga, C. F. and Avendaño-Reyes, L. 2018. Thermoregulatory response to outdoor heat stress of hair sheep females at different physiological state. International Journal Biometeorology, 62(12): 21512160.

Marai, I. F. M., Ayyat, M. S. and Abd ElMonem, U. M. 2001. Growth performance and reproductive traits at first parity of New Zealand white female rabbits as affected by heat stress and its alleviation under Egyptian Characterizing heat stress on livestock using the temperature humidity index (THI) - prospects for a warmer... 2339 conditions. Tropical Animal Health Production, 33:451-462. https://doi.org/10. 1023/A: 1012772311177.

National Bureau of Statistics, 2010.

Nayak, V., Pathak, P. and Adhikary, S. 2018. Rearing Climate Resilient Livestock for Better Productivity. A Review. International Journal of Livestock Research, 8(3), 623.

Nguyen, T. T. T., Bowman, P. J., HaileMariam, M., Pryce, J. E. and Hayes, B. J. 2016. Genomic selection for tolerance to heat stress in Australian dairy cattle. Journal of Dairy Science, 99:2849-2862.

Nienaber, J. A., Hahn, G. L., BrownBrandl, T. M. and Eigenberg, R. 
A. 2007 . Summer Heat Waves-Extreme Years. In Proceedings of the ASABE Annual International Meet ing, Minneapolis, Minnesota, 17-20 June 2007.

Ovimaps. 2018. Ovimap location: Ovi earth imagery date 23th July, 2018.

Piccione, G., Assenza, A., Fazio, F., Grasco, F. and Caola, G. 2007. Serum concentration of calcium phosphate and 1, 25- dihydroxy vitamin $\mathrm{D}_{3}$ in goats (Capra hyrcus): daily rhythms. Journal of Applied Biomedical Sciences, 5:91-96.

Pragna, P., Archana, P. R., Aleena, J., Sejian, V., Krishnan, G., Bagath, M., Manimaran, A., Beena, V. Kurien, E. K., Varma, G. and Bhatta, R. 2016. Heat Stress and Dairy Cow: Impact on Both Milk Yield and Composition. International Journal of Dairy Science, 14: 1-11.

Prendiville, D. J., Lowe, J., Earley, B., Spahr, C. and Kettlewell, P. 2002. Radiotelemetry systems for measuring body temperature. Grange Research Centre, Tunsany, Ireland, Pp. 3789

Rashamol, V. P., Sejian, V., Bagath, M., Krishnan, G., Archana, P. R. and Bhatta, R. 2018. Physiological adaptability of livestock to heat stress: an updated review. Journal of Animal Behavior and Biometeorology, 6:62-71.

Raymond, R. F. 2017. Effect of thermal indices and relationships with milk yield in exotic dairy cows using invasive and non-invasive markers. M.Sc. Dissertation submitted to the School of Post Graduate, Ahmadu Bello University, Zaria.Pp 1-109.

Renaudeau, D., Collin, A. and Yahav, S.
2012. Adaptation to hot climate and strategies to alleviate Heat Stress in livestock production. Animal, 6(5):707-728.

Sailo, L., Gupta, I. D., Das, R. and Chaudhari, M. V. 2017. Physiological Response to Thermal Stress in Sahiwal and Karan Fries Cows. International Journal of Livestock Research, 7:275-83.

Saiya, H. V. 2012. “Aklimatisasi Sapi PO dan Sapi Bali merespon perubahan cuaca di Kabupaten Merauke Papua," M.Sc thesis, Institut Pertanian Bogor, Bogoor. Pp 2335.

SAS. 2002. Statistical Analysis System User Guide. SAS/STAT version 9.0 for windows. SAS institute Inc., Inc Cary, North Carolina, U. S. A.

Shaji, S., Sejian, V., Bagath, M., Mech, A., David, I. C. G., Kurien, E. K., Varma, G. and Bhatta, R. 2016. Adaptive capability as indicated by behavioral and physiological responses, plasma HSP70 level and PBMC HSP70 mRNA expression in Osmanabadi goats subjected to combined (heat and nutritional) stressors. International Journal of Biometeorology, 60:1311-1323.

Singh, A. K., Devi, R., Kumar, P., Kumar, T. and Upadhyay. R. C. 2014. Physiological Changes and Blood Flow in Murrah Buffaloes during summer and winter seasons. Journal of Buffalo Science, 3 (2): 17.

Singh, N., Bharti, P., Baranwal, A., Kumar, V. and Pandey, A. 2018. Ameliorative Measures to Counteract Heat Stress in Dairy Animals of hot sub-humid ecoregion. International Journal of Livestock Research, 8(3), 296-309. 
Smith, B.I. and Risco, C. A. 2005. Management of periparturient disorders in dairy cattle. Veterinary Clinics Food Animal Practice, 21:503-521.

Thatcher, W. W., Flamenbaum, I., Block, J. and Bilby, T. R. 2010. Interrelationships of Heat Stress and Reproduction in Lactating Dairy Cows. High Plains Dairy Conference, Amarillo, Texas. Pp 45-60.

Tuner, L. W., Chastain, J. P., Hemken, R. W., Gates, R. S, and Crist W. L. 1992. Reducing heat stress in dairy cows through sprinkler and fan cooling. Agricultural Engineering, 8:251-256.

Valente, E. E., Chizzotti, M. L., de Oliveira, C. V., Galvão, M. C., Domingues, S. S., de Castro Rodrigues, A. and Ladeira, M. M. 2015. Intake, physiological parameters and behavior of Angus and Nellore bulls subjected to heat stress. Semina Ciências Agrárias, 16:4565-4574.
West, J. W. 1994. Interactions of energy and bovine somatotropin with heat stress. Journal of Dairy Science, 77:2091-2102.

West, J. W. 2002. Effects of Heat-Stress on Production in Dairy Cattle. Journal of Dairy Science, 86: 2131-2144.

Yaqub, L. S., Ayo, J. O., Kawu, M. U. and Rekwot, P. I. 2017. Diurnal thermoregulatory responses in pregnant Yankasa ewes to the dry season in a tropical Savannah. Tropical Animal Health and Production, 49: 1243-1252.

Received: $4^{\text {th }}$ August, 2020 Accepted: $20^{\text {th }}$ December, 2020 